J. of Modern African Studies, 56, 1 (2018), pp. 87-112 (c) Cambridge University Press 2018. This is an Open Access article, distributed under the terms of the Creative Commons Attribution-NonCommercial-ShareAlike licence (http://creativecommons.org/licenses/bync-sa/4.o/), which permits non-commercial re-use, distribution, and reproduction in any medium, provided the same Creative Commons licence is included and the original work is properly cited. The written permission of Cambridge University Press must be obtained for commercial re-use.

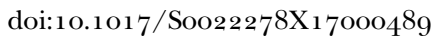

\title{
Land, investments and public- private partnerships: what happened to the Beira Agricultural Growth Corridor in Mozambique?*
}

\author{
RANDI KAARHUS \\ Norwegian University of Life Sciences (NMBU), Noragric, NO-I432 \\ Aas, Norway \\ Email: randi.kaarhus@nmbu.no
}

\section{A B S T R A C T}

Influential discourses present Foreign Direct Investment (FDI) as essential for agricultural development in Africa; a parallel, critical debate on 'land rushes' has denounced Land Grabs, demanding increased accountability in FDIbased land deals. This article explores an initiative located in central Mozambique, the Beira Agricultural Growth Corridor (BAGC). It shows how the international fertiliser company Yara set out to enrol actors at different levels in business, governance and agricultural development into BAGC as a public-private partnership to promote commercial agriculture. Very soon,

* The initial fieldwork on which this article is based was funded by Norad, Norway. Many people have in different ways contributed to the development and encouraged the publication of this article. I wish to thank Ruth Haug, Øystein Botillen, Carlos Mate, Mario Chivale, Stefaan Dondeyne, Lise Stensrud and Ann Helen Azedo for indispensable support, Lars Buur and Rasmus Pedersen for comments on an earlier version of the article, and the journal's reviewers for their fruitful comments. I am also very grateful to a large number of informants who have shared their knowledge and experiences; research ethics and confidentiality considerations have here resulted in anonymisation. 
however, Yara made shifts in its engagement and market strategy, leaving the BAGC initiative to supporting donors and local producers. The analysis presented here shows how the tension between 'patient-capital' requirements, high risks and low immediate returns have shaped this case over time - in a context of a national political economy framed by extractive-resource dynamics.

\section{N T R O D U C T I O N}

At the turn of the century, Mozambique was placed at the bottom of almost all development and poverty indexes. Then followed a time when the country became one of the stars in the 'Africa rising narrative' (Kirshner \& Power 2015). By 2017, however, the country appears enmeshed in a deep and complex crisis-economic, political and social - with continuing poverty in rural areas. Key indicators of the current crisis are a devalued national currency, rising debts, serious corruption and mismanagement charges directed at central-government figures, while the main political opposition party in 2012 returned to armed resistance, later agreeing to join 'peace-negotiations' with the government. ${ }^{1}$ As a setting for diverging discourses, complex challenges and conflictive processes, the Mozambican situation calls for more indepth case studies. The present article gives an account of one case, the Beira Agricultural Growth Corridor (BAGC). The case provides a basis for a discussion of different actors' roles in initiatives to promote commercial agriculture, and the challenges associated with new investments in land and agricultural development in Africa.

The Beira Corridor refers to an area covering three provinces (Sofala, Manica and parts of Tete) in central Mozambique (see Figure 1). Its axis is the historic transport corridor that links the port of Beira on the Indian Ocean with Harare in landlocked Zimbabwe. When an investment blueprint for BAGC was launched internationally in 2009/2010, it outlined highly promising investment possibilities in commercial agriculture in the Beira Corridor, with 'over 10 million hectares of arable land available' of which 'less than 3\%' was commercially exploited (BAGC 2012). The present article provides an analysis of the rationale behind the concept of an 'Agricultural Growth Corridor' and the transformation of this initiative into a fund supporting small- and mediumscale agribusinesses. It shows how changes in the constellation of partners in BAGC as a public-private partnership (PPP) shaped the internal dynamics, as well as the external profile of the initiative. As key actors' priorities shifted, the profile of the investment project also changed. National public partners and local farmers in particular are subject to 
constraints in space and time of a different nature than external investors, since their main assets (land, local knowledge and local networks) are in principle not movable. While the BAGC concept highlighted the importance of 'patient capital', the initiative itself developed in ways that once again brings up questions of time and accountability relations in development initiatives. Hanlon \& Smart (2008: 22) refer to 'the very short time horizons and rapidly shifting priorities' among donors in the field of agricultural development. This article indicates that these characteristics also shape the actions of international corporations.

While official development assistance has moved from public-sector support to a stronger emphasis on private-sector growth, shaping internal dynamics in aid-dependent countries such as Mozambique, the Government itself is pursuing an economic strategy that basically consolidates an extractive resource orientation (Massingue 2015: 82). Foreign investments have over time been channelled towards so-called mega projects - primarily in aluminium processing, mineral, coal and gas extraction. In selected regions, parallel investment initiatives have aimed to install large-scale export-oriented agriculture 'to accompany resource extraction and emergent regional transport infrastructure networks' (Kirshner \& Power 2015: 69). In this context, both international media and scholarly development literature have debated the ProSavana programme in the Nacala Corridor in northern Mozambique. This initiative has both been praised as a model for agricultural development in Africa (Collier \& Dercon 2014: 93), and scrutinised under the heading of innovative South-South Cooperation (Wolford \& Nehring 2015; Shankland \& Gonçalves 2016). It has, moreover, become a highly contested initiative, subject to continued criticism by civil society organisations in the context of recent-years' Land Grabs in Africa (Chichava et al. 2013; Lagerkvist 2014). At the moment of writing, it is still unclear if ProSavana will ever 'take off'; while critical assessments already see signs of a 'failed project' (Shankland \& Gonçalves 2016: $3^{6}$ ).

Though the BAGC initiative was never openly contested like the ProSavana, an environment of risk characterising both large- and smaller-scale agricultural ventures in Mozambique prevails in both cases. As expressed by a local private-sector representative in the Beira Corridor in 2010: 'Here, investments in agriculture are high risk and low return!' ${ }^{2}$ The risk situation in the Beira Corridor was exacerbated in 2012, when the leader of the major opposition party in Mozambique, RENAMO, moved his headquarters to Mt. Gorongosa in 
the Corridor area. During the Mozambican civil war (1977-1992), the RENAMO rebel forces ${ }^{3}$ had several bases in this area (Schafer \& Bell 2002; Schuetze 2015), and the transport corridor was a target of violent attacks by RENAMO forces, while being defended by the FRELIMO government supported by Zimbabwean troops (Smith 1988: 260). During 2013, new attacks by RENAMO militia again targeted road transport in the Corridor, and violent clashes with the Armed Forces and police were reported, until the signing of a peace deal led to a ceasefire around the presidential elections in Mozambique in 2014.4 In 2015 violent clashes resumed, following RENAMO allegations of persistent electoral fraud. RENAMO's leader declared a ceasefire in December 2016, while peace negotiations continued into 2017. These years of armed conflict have directly affected livelihoods in the Beira Corridor, resulting in people leaving rural areas, but also adding to a more general uncertainty about the future - including the future of investments in agricultural development under the BAGC initiative.

This article is based on an extended case study, covering the period 2008-2016/17, with fieldwork periods concentrated to the years 2009-2011. Mitchell (1984: 238) describes an extended case analysis as typically following the same actors through shifting situations, providing a dynamic dimension to the configuration of actors and relationships examined. The account of BAGC given here primarily draws on qualitative data, including a series of interviews during fieldwork periods in 2009-2011, complemented by final interviews and document reviews in 2016/17. The article is structured as follows: The first section situates the study in relation to recent debates on foreign investments (FDI) and 'rushes' to acquire land in Africa, and more specifically the debates on land issues in Mozambique's recent history. The next section introduces the Agricultural Growth Corridor concept, giving an account of how it was used to develop a blueprint for the BAGC initiative within a regional Development Corridor approach. Then follows an analysis of the key actors involved, and of the PPP (public-private partnership) as a vehicle in turning the Agricultural Growth Corridor concept into a blueprint for investments using 'Fast Track' pilots to attract interest in FDI circles. Finally, the article shows how the initial high-profile investment initiative was transformed into a funding and project-support mechanism, involving several international donors in a conflictive public-private partnership - aiming to sustain a limited number of small- and medium-scale agribusiness initiatives. 
DEBATES ON LAND GRABS AND LAND IN A MOZAMBICAN CONTEXT

The BAGC initiative started in 2009; the same year as 'land rushes' both in Africa and at a global scale induced a broad debate - with international media headlines reporting on the rise and fall of a large-scale land deal in Madagascar, involving a South Korean firm and the national government. The 'spectacular fall' of the Ravalomanana government in Madagascar was one factor spurring international attention (Wolford et al. 2013: 190); another was the size of the land area involved in the planned deal, reported to be 1.3 million hectares (Cotula et al. 20og: 3). The international debate presented both critical analyses and mounting evidence on land acquisitions and land deals of a potentially enormous scale and speed (White et al. 2012: 624). Authors drew attention to the convergence of crises in several fields - finance, energy and climate - in combination with the dramatic increase in world food prices in the period 2007-2008 (Scoones et al. 2013: 472). This convergence was also used to explain why powerful transnational corporations searched for available 'idle' or 'empty' land to be used for future food and biofuel production (Borras et al. 2011).

From the beginning, the debate on Land Grabs was particularly concerned with corporate and transnational takeover of smallholders' land. In an African context, large-scale takeovers also represented historical continuities with earlier colonial land rushes (Alden Wily 2012; White et al. 2012), and FDIs were associated with 'neo-colonial scrambles for land and resources conducted by predatory investors' (Wolford et al. 2013: 191). An overriding concern was the size of the land areas involved. Though cautions were made on the limited reliability of available data on land acquisitions (Cotula et al. 2009: 40), aggregated information of uneven quality on deals and hectares tended to be presented as facts (Edelman 2013: 485). Considerable uncertainty about how much land had actually been 'grabbed' soon led the debate into a new phase, with calls for empirical studies of the complex relationships between investors, state actors and other institutions involved (cf. Fairbarn 2013).

The existing literature on transformations in land tenure in contemporary Mozambique mostly engages with two phases in the country's modern history. After gaining independence from Portugal in 1975, and with a government established under the leadership of FRELIMO (the Mozambican Liberation Front), only a few years passed before the country was immersed in a violent civil war. When this devastating war ended with a peace accord in 1992, the situation concerning land 
access and landownership was unsettled, involving competing and overlapping land claims (Myers 1994). Under FRELIMO's socialist development agenda, an agricultural sector consisting of large-scale state farms had been prioritised. As an agricultural development model it met with resistance from local people, and has been seen as one of the factors behind the protracted civil war (Geffray 1990; Lubkemann 2008). Towards the end of the war, the IFIs 5 presented a conditionality package to the Mozambican government. It was implemented through extensive structural adjustment and policy liberalisation in the country (Abrahamsson \& Nilsson 1995; Hanlon 1996; Pitcher 2002; Taylor 2003). The liberalisation policies also spurred the privatisation of state-farm land. The state-farm sector was in 1991 estimated to cover at least 6oo,ooo ha (Myers 1994: 6og). Privatisation was implemented through a 'chaotic alienation of land, including land grabbing and speculation' (West \& Myers 1996: 29). Land rights were granted to private enterprises and government officials, while former state-farm land was rarely given to smallholders. After this process of privatisation and restructuration of the Mozambican economy, the major foreign private investors in agriculture and agro-processing were mainly British, South African and Portuguese (Pitcher 2002: 208; cf. Hall 2012 ); while FRELIMO government officials had also acquired substantial land areas.

With the Mozambican peace accord in 1992, millions of displaced people returned to their areas of origin in the countryside, and the land question was one of the urgent problems to be addressed. Research on land issues in this period (e.g. Myers 1994; Gengenbach 1998; Waterhouse \& Vijfhuizen 2001; Negrão 2003) addressed the widely recognised need for a new national land legislation, and research findings fed into broader debates among political and civil society actors. A new Mozambican Land Law was enacted in 1997, aiming to secure access to land for the large majority of people in the countryside, including people who had been displaced during the war, while also providing regulated access to land for private investors. Thus it succeeded in settling many of the contentious issues concerning access and competing claims to land of the early 199os. In the debate on Land Grabs starting in 2oog, Mozambican land tenure relations have again been shown to involve conflicts (Ribeiro \& Matavel 2009; Hanlon 2011; Tanner 2011 ; Cotula 2012; Hall 2012; Chichava et al. 2013). While new deals involving transnational and foreign investors have been in focus, some studies also relate to the internal Land Grabs of the 19gos (e.g. Fairbarn 2013; Milgroom 2015), when 'government officials or others 
well-connected politically' (West \& Myers 1996: 40, fn. 23) were able to acquire much of the best agricultural lands. It can be argued that former state-farm land for some time may serve as an 'available-land reservoir' for the Mozambican state when allocating land for new investment initiatives, as well as for a well-connected elite making more direct deals with external investors. When this reservoir runs low, land currently used by smallholders may easily come under increasing pressure and be targeted for FDI ventures justified by national-development interests. This can lead to new conflicts over agricultural land, as well as new challenges to Mozambican policymakers envisioning land use either as a basic resource sustaining precarious rural livelihoods, as a target for investments in large-scale agricultural development, or as a field for testing 'hybrid' alternatives in-between (Smart \& Hanlon 2014).

THE AGRICULTURAL GROWTH CORRIDOR CONGEPT

The Agricultural Growth Corridor concept was first presented by the international fertiliser company Yara in 2008, at a Private Sector Forum organised as a side event to the UN General Assembly in New York. Yara launched it as a 'partnership concept', with an overall aim to 'develop underutilised land areas in Africa' as part of the company's 'Africa engagement' (Yara 2016). Yara is at present one of the world's largest producers of mineral fertiliser; a production which started in Norway in 1905 . Operating under the name Hydro, the fertiliser company over time diversified its portfolio both in Norway and internationally. In 2004, the fertiliser production split off and established itself as a separate company, Yara International ASA. ${ }^{6}$ The same year, former Secretary-General Kofi Annan made a call for an African Green Revolution, and encouraged the creation of new partnerships to end the long-term neglect of African agriculture. Yara saw Annan's call as a timely opportunity, and came up with the Agricultural Growth Corridor concept as a private-sector response, presenting it at successive high-level events between 2008 and 2011.

As a partnership concept, the Agricultural Growth Corridor was directed at private-sector investors, as well as national public partners in Africa, but also addressed the international community of donors. Yara had already worked with the Alliance for a Green Revolution in Africa (AGRA), established in 2006 with the aim of dramatically improving African agriculture. When Yara launched the Agricultural Growth Corridor concept in 2008 , it was as a partnership concept linked to a specific development model, the value-chain, within a Green 
Revolution framework. From the early 20oos, the value chain model has been used in business company management, as well as in investment discourses. Serving both as an operational approach and as an analytical tool (Ouma et al. 2013), it was soon adopted by donors in international development, including agricultural development agencies. As a marketoriented, input-output model, the value chain is meant to represent the processing of a commodity from production to consumption. ${ }^{7}$ In agriculture, introducing a value-chain approach implies turning subsistence-oriented farmers into (more) credible suppliers of marketable commodities. This requires promotion and facilitation of increased uses of agricultural inputs such as certified seeds and mineral fertiliser to increase productivity. Yara had obvious interests in increasing demands for fertiliser, envisioning new markets among both larger and smaller-scale farmers in Africa. In Yara's view, the 'underutilised land areas in Africa' needed 'large-scale investments to shift the agricultural landscape and transform subsistence farming into viable businesses' (Yara 2016). To get there, the proposed concept involved using PPPs as a vehicle to develop value chains in Agricultural Growth Corridors in selected regions.

The Beira Corridor in Mozambique was on the agenda when Yara, in collaboration with AGRA, in January 2009 organised a roundtable at the World Economic Forum (WEF) in Davos. ${ }^{8}$ The Mozambican Prime Minister Luisa Diogo attended the presentation, and confirmed that the Government of Mozambique would be willing to come in as a public partner. In Mozambique, the Land Law of 1997 provided possibilities of regulated access to land through long-term leases (up to 99 years) for both national and international investors. In 2009, after more than a decade of growth in the national GDP, investments in domestic agricultural development were still insignificant. Among my interviewees, a former FRELIMO Minister stated clearly: 'In Mozambique, nobody wants to invest in small-scale family agriculture' 9 In the words of a businesswoman from the Beira region: 'People here put capital into property-abroad. It's a risky environment for agriculture'. ${ }^{10}$

The Mozambican Government had established an Investment Promotion Centre (CPI) to support and assist investors, both foreign and domestic, and further handle the approvals necessary to make FDIs in Mozambique (U.S. Department of State 2012). In 2009, the Government proceeded to create a Special Economic Zones Office (GAZEDA $)^{11}$ to work specifically with the establishment of Industrial Free Zones and Special Economic Zones, following the trend of other 
governments around the globe 'to link extractive frontiers to metropolitan areas and foreign markets' (White et al. 2012: 629). The Mozambican Government had also set up a Centre for the Promotion of Agriculture (CEPAGRI) to facilitate public-private partnerships in the agricultural sector, and give advice to foreign investors in cases where foreign direct investments would involve large-scale land acquisitions. ${ }^{12}$ The concept of Agricultural Growth Corridors could furthermore be linked to the already identified Development Corridors within the so-called Spatial Development Initiatives (SDIs), launched in the larger region in the $1990 \mathrm{os}$.

The SDI-corridor projects had focused on transport infrastructure and non-renewable natural resource extraction for exports; the general idea being 'to attract export-driven investments and stimulate public-private partnerships to areas with under- or unutilized potential' (Meeuws 2004: 62). The corridors connected inland regions with exploitable resources to the ports on the Indian Ocean coast in Maputo, Beira and Nacala, or were based on major waterways, such as the Zambezi and Limpopo rivers. Several of the corridors could trace their history back to transport and migration routes connecting the colonial coastal ports of Portuguese East Africa to the British colonies in the interior; to the mineral-based industries in Transvaal (South Africa) for the Maputo Corridor, to the expanding large-scale agriculture in Southern Rhodesia (now Zimbabwe) in the case of the Beira Corridor, and in British Nyasaland (now Malawi) for the Nacala Corridor. Later, the Beira Corridor had been particularly important as an outlet to the sea for the land-locked neighbour Zimbabwe. With the fall of apartheid in South Africa and the 1992 peace accord in Mozambique, the South African government soon became a driving partner for the regional SDIs, with a particular interest in developing the Maputo Corridor. By 2009, the other Corridors still lacked large-scale investment prospects. Thus, the Mozambican Government no doubt saw a convergence between the Agricultural Growth Corridor initiative and its own interests in promoting the Development Corridors. The distinctive feature of the Agricultural Growth Corridor concept in the SDI context was, however, its focus on agriculture. ${ }^{13}$ That is, promoting economic growth through linking the development of commercial agriculture to other large-scale investment projects in a spatially delimited area surrounding an axis of transport infrastructure.

The professionals who were recruited by Yara in 2009 to develop the concept of an Agricultural Growth Corridor considered commercial agriculture in this part of Africa to be "at the very earliest "greenfield" stage 
of development' (Palmer 2010: 5). Greenfield investments is part of FDI terminology, referring to investments involving the establishment of new production facilities in a foreign country (Eun \& Resnick 2007: 404). In the development of the Agricultural Growth Corridor concept, investment in 'greenfield agriculture' is in principle associated with high risk and low profitability (Palmer 2010: 8), indicating that private investments require public facilitation and funding. Conventional FDI discourse (Lee \& Ries 2016: 206) also indicates that in many developing countries 'a critical level of aid is required to encourage greenfield investment'. Directing greenfield investment to an Agricultural Growth Corridor further presupposes the creation of a 'special space' - with strategies for facilitation and exceptions from at least some constraining rules and regulations. The PPP is here a vehicle aiming to facilitate this special-space treatment.

The 'greenfield space' can be said to bring in connotations, or an 'imaginary' (Shankland \& Gonçalves 2016: 36), of starting from 'a clean slate or tabula rasa' (Kennedy \& Sood 2016: 42). For local people, the same space will normally be perceived in terms of a 'thickness' of uses and structures, of power and meaning 'superimposed upon or knotted into one another' (Geertz 1973: 10), referring to history and conflicts, interests, rights and claims, as well as often conflicting aspirations for the future. For Yara as an agribusiness company, the cultivable land areas along the Beira Corridor basically represented resources with a potential for larger-scale agriculture, which would in turn result in increasing demands for agricultural inputs. The existing infrastructure axis of road and rail could be upgraded to carry loads of mineral fertiliser from the port of Beira to the inland region, beyond central Mozambique into Zimbabwe and Zambia. The main road in the Beira Corridor further connected the inland province of Tete, with its new mega-projects in coal mining, to Beira port (Figure 1). With a rapidly expanding coal extraction industry, there were expectations that new demands for food products would provide a market for larger-scale agribusiness initiatives in the region. Finally, Yara had its own investment plans. A key element in BAGC was the construction of a fertiliser terminal as part of a larger development plan for Beira port.

B AGC FROM CONCEPT TO PRACTICE

Based on the interest expressed by the Government of Mozambique at the WEF roundtable in Davos in January 2009, Yara had the agricultural growth corridor initiative concretised into a report with a blueprint for 


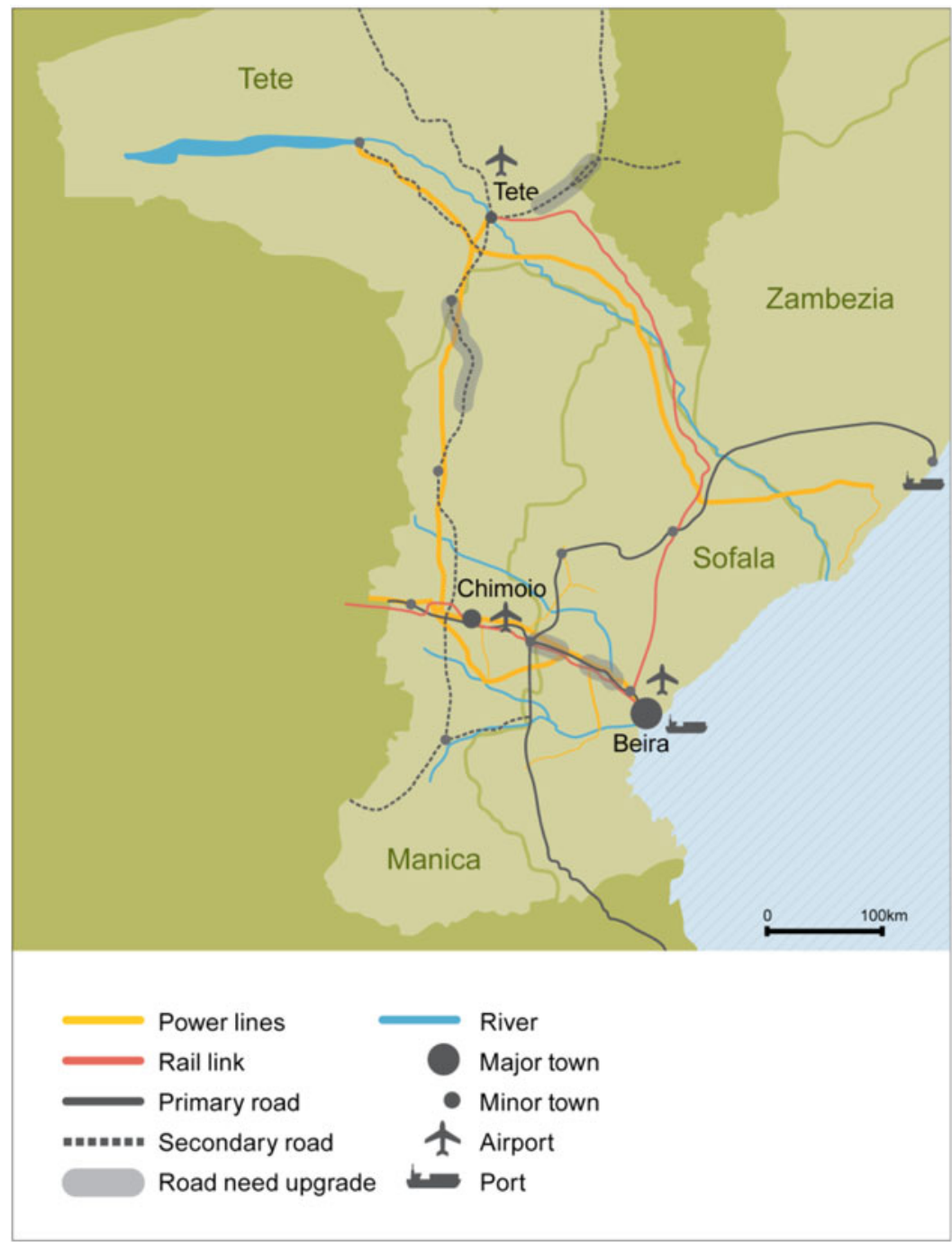

Figure 1 Envisioning BAGC in geographical space. Developed as part of the BAGC concept; replicated with permission from Yara through NMBU, Norway.

investments: Beira Agricultural Growth Corridor: Delivering the Potential (BAGC Report 2010). Three UK-based consulting-and-development companies were involved: Prorustica, InfraCo and AgDevCo. ${ }^{14}$ Operating at the public-private interface, these companies were familiar with the priorities, models and discourses of both public and private actors in the field of agriculture and development. Yara itself was 
particularly concerned with the time factor, and wanted a complete blueprint for investments to a short deadline. ${ }^{15}$ The BAGC blueprint report was ready - on time - in January 2010, when Yara organised a first Partnership (PPP) meeting in Maputo. Immediately after this meeting, Yara had the proposal launched at WEF in Davos. Only a month later, the Norwegian Minister of Development Erik Solheim visited Mozambique and attended another launch, at the projected site for Yara's fertiliser blender at Beira port. At this event, the public sector in the PPP was further represented by CEPAGRI (for the Mozambican Government) and the Norwegian Embassy in Maputo, while the private sector was represented by the local business association ACIS in Beira, and by Yara as lead partner in the PPP.

When I visited Beira port only a month after the launch, there were no signs of activities linked to the BAGC initiative or Yara's plans to construct a new fertiliser terminal. A few people working in the harbour had vague memories of a meeting with high-level people, but they had apparently never come back. When I met representatives from the local business association, ACIS, they said it was difficult to communicate with Yara representatives, and they wondered about their own role in the new partnership. ACIS had contributed to the process: 'For Davos, they needed statements for support. Then there was pressure to have a proposal before Solheim came, so that he would endorse it. But the proposal is not that tangible ...' ${ }_{16}$

It turned out that after the rush to present a ready-made blueprint for the successive launches in early 2010, Yara received studies of soil mechanics and water-logging at the projected construction site for the fertiliser blender. These revealed that the costs of construction on the projected site were much higher than expected. ${ }^{17}$ At the same time, other initiatives within the company resulted in the sale of Yara's retail marketing businesses in southern Africa. ${ }^{18}$ With a quick shift in priorities, Yara by mid-2010 turned to a corridor project considered to involve less risk and no conflicting business commitments, the Southern Agricultural Development Corridor of Tanzania (SAGCOT). Moving swiftly, Yara was able to present a blueprint for the SAGCOT initiative in January 2011, at that year's WEF in Davos. When the Norwegian Minister of Development Solheim visited Tanzania in February 2011, he pledged further support from the Norwegian Government for the development of the SAGCOT initiative. Replicating parts of his speech at the BAGC launch in Beira less than a year earlier, the Minister asserted that: 'The goal is increased growth, increasing food production, and to contribute to a green 
revolution in the country', and continued: 'This can be a model for other countries' (Norwegian Government 2011). ${ }^{19}$ Less than four years later, in September 2015, Yara opened a new fertiliser blender in Dar es Salaam, as part of the ongoing SAGCOT corridor project in Tanzania. What happened to BAGC?

LAND, PARTNERS AND MODELS FOR COMMERCIAL FARMING

In the original presentations of the Beira Agricultural Growth Corridor a recurring discursive figure was 'over 10 million hectares of arable land available' with 'less than 3\%' as yet commercially exploited (BAGC Report 2010). The figure Io million ha highlighted the agro-investment opportunities for FDIs in the Beira Corridor. Government officials in Mozambique would generally hold that there was a lot of land available in the country, and the official view was that pressure on land was not a problem. To what extent and under what conditions land is actually 'available' for investments has, however, increasingly become an issue of debate and contestation in Mozambique (Åkesson et al. 2008; Tanner 2011; Shankland \& Gonçalves 2016). Borras et al. (2011: 215) uses the case of the large-scale biofuel project ProCana in the south to assert that 'the assumption about existing, available marginal lands is fundamentally flawed'. In principle, the Mozambican Land Law secures rural people's established user and access rights (Kaarhus \& Dondeyne 2015). On the other hand, all land is in legal terms the property of the State; which also involves a state apparatus operating as an economic actor promoting investments in land, assisting investors in finding appropriate land, and 'relocating individuals currently occupying land designated for development' (U.S. Department of State 2012).

During my fieldwork in 2010 , representatives of the Provincial association of small farmers in Manica, UCAMA, ${ }^{20}$ were sceptical of new investments in commercial agriculture in their area, and concerned that BAGC would present a threat to members' rights and interests in land. They held that all land in the Corridor area with reasonable access to transport facilities was already occupied; but also held that '.. when you leave the accessible areas, there is lots of land'. The $I O$ million hectares figure was unknown at the local level. As presented in the BAGC Report (2010: 15), this figure was a product of the assessment presented in Table I.

The BAGC assessment defined the Beira Corridor area as covering the three provinces Sofala, Manica and Tete. ${ }^{21}$ It characterised $44 \%$ of the 
TABLE I.

BAGC area land assessment.

\begin{tabular}{|c|c|c|}
\hline Total land area in Manica, Tete and Sofala provinces: & $23,000,000$ ha & $(100 \%)$ \\
\hline Arable land (based on soils and climatic suitability): & $10,000,000$ ha & $(44 \%)$ \\
\hline $\begin{array}{l}\text { Land suitable for irrigation (with proximity to transport } \\
\text { infrastructure): }\end{array}$ & 300, ooo ha & $(1 \cdot 3 \%)$ \\
\hline $\begin{array}{l}\text { Suitable land for new commercial farming (Taking into account } \\
\text { market assessments for selected value chains): }\end{array}$ & 9o,ooo ha & $(0.9 \%)$ \\
\hline
\end{tabular}

Source: BAGC Report (2010:15).

total land area in these provinces (10 million ha) as 'arable land' based on technical criteria such as soils and climate. The assessment found 300,000 ha of the 10 million to be of interest to investors in commercial irrigated agriculture, taking into account access to transport infrastructure. Based on a value-chain approach, the blueprint identified a number of products with commercial potential: maize, wheat, rice, soya, citrus, mango, banana and sugarcane (BAGC Report 2010). Only 90,0oo ha was classified as suitable for agricultural ventures to develop value chains for these products.

As an agricultural development initiative, BAGC was based on assumptions about the benefits of economies of scale. In the broader literature on agricultural development, scale has been a much debated and contested issue. ${ }^{22}$ In a background paper delineating a conceptual framework for BAGC, Palmer claims that: '... small farmers cannot generate enough value to pay for the cost of installing infrastructure with its high fixed costs' (Palmer 2010: fn 12). But the BAGC Report (2010) makes it clear that neither can large-scale commercial ventures in 'greenfield agriculture' be expected to pay for these costs. The solution presented is access to patient capital, defined as 'long-term capital made available by the international community on concessional terms' (Palmer 2010: 11). The BAGC concept was based on both public investments and donor funding being made available to develop the necessary infrastructure to make this region attractive to FDI investors. A critical analysis of the discourse promoting BAGC shows that it highlighted the opportunities for FDI in land, with PPPs as vehicles to develop commercial agriculture. While the high-profile BAGC launches sought to attract interest among FDI investors, the BAGC Report (2010) pointed to the need for mobilising 'patient capital' from public and donor sources in order to make investments attractive 
for private investors. However, very soon Yara's own withdrawal from a role as an active investor in the initiative demonstrated that the key convenor among the private sector partners itself rather operated with 'impatient' capital.

From the start, representatives of some of the main donor agencies in Mozambique were sceptical about BAGC. One said: 'BAGC cannot come here with just big concepts. There is nothing here!' A representative of another agency held that: 'What we lack is an overall strategic dialogue! In the Ministry, few have real contact with agriculture.'23 BAGC was based on a vision of convergence of private-sector interests and publicpolicy models for development. At the same time, the public-privatepartnership model provided for a flexible organisation, permitting shifting positions for those who joined as partners in the alliance. In more concrete terms, the BAGC approach involved linking largerscale commercial farming ventures to selected local smallholders in promising value chains. Two main models were delineated: (1) The outgrower model, with a commercial farm as a hub providing services, such as irrigation or storehouse facilities; (2) The serviced farm blocks (also called 'in-grower') model, with a serviced and preferably irrigated area managed by a commercial leasing company, sub-leasing farm blocks of different sizes to both larger-scale and small-scale farmers (BAGC Report 2010: 22). Both models fall under the more general category of contract farming, referring to pre-agreed supply arrangements between producers and buyers in a value chain. Historically, sub-contracting has been regularly used in Mozambique, and local farmers have been involved in pre-established arrangements to grow and deliver specified amounts of produce - e.g. sugar cane or cashew - of a specified quality at an agreed date (Vermeulen \& Cotula 2010: 39; Buur et al. 2011). As a general model, contract farming addresses some of the problems of risk and scale in agricultural value chains aiming to supply regional and global markets. As such it involves mechanisms to comply with established quality standards and timely delivery. On the other hand, contract farming entails its own problems and challenges. These may be related to enforcement of agreements, power-relations in decision-making, responsibilities for outcomes, as well as conflicts in relations of dependency; though in practice a broad variety of arrangements prevail (Smart \& Hanlon 2014). In this context, the BAGC Report (2010) presents a business-oriented discourse pointing to opportunities, while problems and obstacles are left out of the picture. Seeking to promote FDIs in Mozambican agriculture, Yara had commissioned a report with a blueprint for pilot projects that 
could deliver as 'Fast-Track opportunities' (BAGC Report 2010: 8), targeting investors with more 'impatient' capital.

The BAGC partnership never developed into the envisioned coordinating framework for large-scale investments in agricultural development in the Beira Corridor. Yara's shift to SAGCOT in Tanzania in early 2011 was no doubt an important factor in this regard. But a few donors stayed on. A representative of the British Department for International Development ${ }^{24}$ during an interview in 2010 held that: 'Yara's vision is limited'. The Norwegian Embassy in Maputo set up a Catalytic Fund to finance a number of the agricultural business initiatives that the BAGC Report had identified as Fast-Track pilots. By 2011, both DfID and the Dutch Embassy in Maputo had joined as funding partners in the BAGC Catalytic Fund. The donors contracted the UK-based AgDevCo to manage the Catalytic Fund - as a preliminary arrangement until a national investment company could be established (Carnegie Consult 2015). With support from the Norwegian Embassy, a BAGC institutional structure was set up, including: (1) A Partnership registered as a civil society association in Mozambique; formally operating with a board and a secretariat; (2) The Catalytic Fund, with its own board and an investment committee, and AgDevCo serving in the key role as fund manager.

After Yara's withdrawal as a lead partner in BAGC, the geographical centre of the initiative shifted from the port of Beira to the upland province of Manica and its capital Chimoio. ${ }^{25}$ Most of the 'pilots' that received funding from the Catalytic Fund were also located in Manica province. They were small- and medium-scale agribusinesses, with BAGC entering as one among several sources of funding and support. ${ }^{26}$ The pilots were involved in various forms of agricultural production, including seed multiplication and wild honey collection, and small-scale soya, goats and pig-meat processing. Only four of the agribusinesses would eventually operate in the value chains identified in the BAGC blueprint. ${ }^{27}$

The 'investees' who were directly involved in agricultural production were basically operating on former state-farm land. These state farms had been established on some of the best agricultural land in the province of Manica. At Independence this land was occupied by colonos who had been recruited from Portugal in the 193 os and the early 1960 , and granted land - and support - from the colonial power to set up modern 
family farms in so-called colonatos (Newitt 1995: 466). From 1989 onwards, the re-privatisation of state farms in the Manica area resulted in this same land being granted to an emerging business elite of higher-level party officials and public servants. These were usually absentee landowners with residence in the national or provincial capital. Some of the farms were for a period worked by former white farmers from Zimbabwe, who moved into Manica province as a result of the country's Fast Track Land Reform and the farm invasions starting in Zimbabwe in the year 2000. However, many of the Zimbabweans encountered serious problems in running commercial farms on an economically sustainable basis in Mozambique (Hanlon \& Smart 2008: 71-88; Hammar 2013). A few stayed on; one of them asserting: 'Here you need time, to get things done. ${ }^{2} 8$

For the BAGC initiative, the former state-farm land, now private-held or leased, represented a reservoir available for new ventures in commercial agriculture. Another resource drawn upon in the fairly down-toearth development of the BAGC pilots from 2011 onwards, was the farming and business management experience possessed by a few remaining ex-farmers from Zimbabwe and some resident South Africans. In contrast to the South Africans, the Zimbabwean farmers themselves had at this point very little or no financial capital left. BAGC set out to promote and fund emerging agro-investments at a moderate scale; supporting this fairly cosmopolitan agri-business environment in the Chimoio area, without local smallholders' land being directly targeted - or affected. Still the business initiatives that were supported by the Catalytic Fund were expected to provide income opportunities for associated smallholders, especially through contract farming. According to the information presented on the Beira Corridor website in 2015, Catalytic Fund projects had 'directly benefitted ... over ten thousand smallholder farmers' (Beira Corridor 2015). Two years later, a DfID Project Completion Review reported that approximately 100,000 smallholders had been 'engaged' - if not in contract farming, through getting access to improved seeds, fertiliser or markets. ${ }^{29}$ In 2017 , around half of the pilots are still operating; some are also profitable in business-economy terms. The people behind these relative successes have invested impressive amounts of commitment, struggling to operate in a local context marked by the problematic security situation resulting from the outbursts of violent political conflict between 2013 and 2016, and the general uncertainty resulting from the national political-economic crisis and the devaluation of the national currency. 
MODELS, ROLES AND PRIORITIES IN PUBLIC-PRIVATE

P A R T N E R S H I P S

In an early phase of the BAGC initiative, both Yara and the Norwegian Government played important roles; one as a 'catalyst', the other through provision of 'seed money'. The role played by the Norwegian Minister of Development when demonstrating political support at the BAGC launch in Beira and pledging continued Norwegian funding for the initiative has several interpretations. It can be seen as an example of support to a global agribusiness actor - Yara - from its 'home government', but also as a signal of the shift in aid away from untied development cooperation. It further signalled a shift in priorities from public-sector institution building towards facilitating 'real growth' in the private sector. With this policy shift, the means also changed, resulting in a stronger emphasis on public-private partnerships. Yara initially assumed a key role in the BAGC initiative; then its role shifted to only a nominal partner in the course of 2010. The company's initial role was no doubt based on its interests to create an expanding market for commercial fertiliser, but also on ambitions to develop its profile as a socially responsible global agribusiness company. Using high-level events to promote an African Green Revolution through PPPs in agricultural growth corridors, Yara set out to mobilise influential actors as partners in its quest to achieve the envisioned 'transformation of African agriculture from subsistence farming to profitable entrepreneurship' (Yara 2011).

When accepting to join the public-private BAGC partnership, the Mozambican Government already had some experience with development corridors as SDI initiatives realised through PPPs. As these SDIs had been conceived on the background of neoliberal policy reforms and the down-sizing of the African state initiated in the late 1980s, the public partners in the SDIs primarily had the role of facilitating and ensuring an enabling environment for market actors (Taylor 2003; Söderbaum \& Taylor 2008a). South African capital had contributed to infrastructure projects such as the major cross-border toll road (Maputo-Witbank) when the Maputo Development Corridor started to materialise in the late 1990s. The construction of the large aluminium smelter (MOZAL) in the Maputo Corridor was also a result of foreign investments, while the Mozambican Government contributed by defining MOZAL as an Industrial Free Zone with corresponding tax exemptions. Within the Southern African Development Community (SADC), the Maputo Development Corridor was considered a success with a 'strong emphasis on commercial viability' (Söderbaum \& Taylor 
2008b: 42). The other development corridors in Mozambique were in the early 2000 considered less successful (Nuvunga 2008); a Trade and Transport Facilitation Audit made for the World Bank stating that Beira was 'still waiting for a mega project like MOZAL in Maputo' (Meeuws 2004: 73). In 2009, Yara's plan for a fertilizer blender at Beira port was not precisely a mega project, but still represented FDI at a scale that the Mozambican Government could probably not decline.

Until BAGC entered the scene, development corridors in Mozambique had in practice focused on infrastructure development and prioritised the development of extractive and processing industries in 'enclave spaces' (Kirshner \& Power 2015). Private-sector capital had through the PPPs secured investments in corridor infrastructure. This was a feasible approach when the private actors involved in joint ventures were multinational corporations in extractive industries and mineral processing. The Agricultural Growth Corridor concept, by contrast, aimed to involve public partners in more active roles. The government was expected to take on more responsibilities, dedicating public funds for infrastructure development. Combined with donor funding, this was expected to make the corridor attractive for private investments in commercial agriculture. Given the established SDI framework - and a more generalised lack of political prioritisation of the agriculture sector after the disintegration of the state farms around 1990 - it is not obvious that the Mozambican government was prepared to fill this role. Mozambican authorities furthermore considered another of the planned SDI corridors to have greater immediate potential. This was the Nacala Corridor, linking the deep sea port of Nacala - one of the best natural harbours on the Indian Ocean - to the fertile lands in the province of Nampula, and through Malawi to Tete province. By 2009, no development strategy for the Nacala Corridor had yet appeared (World Bank 2010: 22). In 2010, when I had the opportunity to interview several Mozambican officials about the BAGC initiative, I found that it was met with reserved enthusiasm. In an interview in the Ministry of Transport and Communications in Maputo, the official said politely that BAGC was an interesting initiative: 'But, I must admit that Nacala has a better natural harbour ...' $3^{\circ}$

In the following years, the Nacala Corridor alternative soared as a large-scale - and soon widely contested-complex of development plans and PPP alliances. It included infrastructure development in Nacala port; a transport line from the harbour to the coal extraction industry in Tete province, where the Brazilian company Vale was heavily involved in coal extraction; in addition to the ProSavana 
Programme with plans for agricultural development along the Nacala Corridor. The historical roots of ProSavana was the cooperation between Japan, the USA and Brazil to transform the Cerrado grasslands on the Brazilian Plateau into a highly productive agricultural frontier, producing soybeans for the global market (Wolford \& Nehring 2015). In 2010, the Japan International Cooperation Agency (JICA) and the Brazilian agricultural research institute (Embrapa) entered a new Japan-Brazil-Mozambique Tripartite Cooperation on Tropical Savana Agriculture. The 'Cerrado model' itself was contested within Brazil, especially among civil society organizations such as MST - the Brazilian Landless Rural Workers Movement (Oliveira 2013). As an influential member of the international union of smallholders, Via Campesina, MST had close connections with the Mozambican UNAC, and these civil-society networks and alliances contributed to make ProSavana subject to public debate and protests at a scale that the BAGC initiative never encountered.

Though sharing a number of development-model characteristics with ProSavana, the BAGC initiative in the Beira Corridor continued as a low-key PPP, without mobilising civil-society contestation. With Yara's withdrawal of investments plans in Beira port in 2010, there were - in contrast to ProSavana-no major FDI investments connected to BAGC. Neither did Mozambican authorities come up with special incentives or exemptions from state rules and regulations. The initiative basically counted on support and project funding made available by European donors. Their involvement created opportunities for a total of 17 mostly small-scale agribusinesses located in the Corridor area. It also created opportunities for development actors operating as intermediaries and facilitators at the interface between donors, private companies and public institutions. Among the consultancy-and-development companies originally involved in designing the BAGC blueprint in 2010, AgDevCo would from 2011 onwards assume an increasingly important role in the development of the agribusiness initiatives supported by the BAGC Catalytic Fund. It was able to expand its operations to a number of African countries in addition to Mozambique, also acting as a more independent investor in the agriculture sector, through providing 'long-term, flexible risk capital, which is structured to help early-stage businesses reach profitability and scale' (AgDevCo 2017). The company's professional role performance no doubt contributed to several of the BAGC pilot projects considering themselves as AgDevCo clients rather than as BAGC pilots; while the established PPP partnership itself was struggling with disagreements, confusion and mistrust (Carnegie 
Consult 2015). In 2015, the BAGC donors decided to 'exit the BAGC Partnership and withdraw from the 14 remaining investments of the BAGC Catalytic Fund'. ${ }^{31}$ It was further agreed that DfID should oversee an exit plan for the 'catalytic' investments managed by AgDevCo.

As a 'greenfield' initiative to promote large-scale commercial agriculture, BAGC was introduced into a high-risk environment characterised by economic and socio-political constraints that have shaped the opportunities to develop the region's agricultural potential. Historically, the local population of small-scale farmers in this region were never the primary beneficiaries, neither of colonial-era agricultural colonato arrangements, of later large-scale state farm establishments, or of the privatisation of the same farms at the end of the Civil War in 1992. At present, Mozambique has established a legal framework, not only to protect rural people's user rights to land, but also to secure consultations with local people in cases where new investments in land and natural resources may affect their access rights and livelihoods (Tanner 2011). The extent to which this legal framework in practice serves to protect local people's rights and interests has been questioned (Hanlon 2011; Milgroom 2015). Still, it sets a standard. Nevertheless, when potentially large-scale investments aim to increase agricultural production, and promise to bring in expertise, technology and finance, the Government tends to see national-development interests as opposed to smallholders rights - and local-development priorities. In the global Land Grab debate, as well as in the protests against ProSavana within Mozambique, we see that large-scale FDIs in agricultural land may result in broad-based contestation. What comes up as a key question in this context is what type of capital investments is most likely to become subject to forceful demands for public accountability (Shankland \& Gonçalves 2016: 43). And here we talk of accountability demands that go beyond the companies' own ambitions in terms of socially responsible agribusiness, and even beyond international organisations' responsible business standards (OECD-FAO 2016).

In April 2016, Yara bought the regional distribution company Greenbelt Fertilisers, including a fertiliser blending plant at Beira port. Already in February 2017, this fertiliser facility was closed down; but in July 2017 Yara signed a new Memorandum of Understanding with the Government of Mozambique about a new fertiliser plant in 
the northern Cabo Delgado province, using gas from the planned offshore projects in the Rovuma Basin. Thus Yara linked its renewed presence in Mozambique to the extractive-economy sector, rather than to high-risk and potentially contested Agricultural Corridor development initiatives.

In the narrative presented here, we see that new public-private partnerships may bring up unresolved questions of accountability. Publicprivate partnerships aiming to promote agricultural development can in the Mozambican context easily exacerbate existing power imbalances and strengthen extractive-economy trends. When PPPs are associated with large-scale FDIs in agricultural land, as in the case of ProSavana, responses may take the form of open contestation. If agriculture in this region is particularly high-risk and low-return, the term 'patient capital' - a key concept in the Agricultural Development Corridor approach - itself points to some of the inherent dilemmas of neoliberal globalisation as it is played out in initiatives to develop commercial agriculture in Africa. In a PPP of unequal partners, the question of who remains with the risks, and who is left to pay the debts, becomes acute when some partners leave, subject to their own shifting priorities or the imperative of short-term profits. Others have to stay-with the risks, debts and uncertainties involved.

On the other hand, if FDI directed towards extractive-economy ventures in mining, oil and gas more easily escape widespread demands for public accountability, what implications do we see for investments in agriculture? Can we draw the conclusion that FDIs should be de-linked from agricultural-land development? In that case, national as well as international public actors need to increase their direct support and commitment to agricultural development - at appropriate scales, and in ways that take local knowledge, local investment priorities and local time horizons seriously. The experiences represented by the remaining actors in the BAGC Catalytic Fund may provide valuable lessons informing such a reorientation.

\section{NOTES}

1. Cf. http://clubofmozambique.com/news/metical-revaluing-hanlon/; http://clubofmozambique. com/news/mozambique-is-suffering-a-military-expression-of-a-political-problem/; http://www.u4.no/ publications/mozambique-overview-of-corruption-and-anti-corruption/; http://www.pgr.gov.mz/images/ documentos/comunicados/Independent_Audit_Executive_Summary_English_(REDACTED_FOR_ PUBLISHING).pdf, accessed 7.7.2017.

2. Interview with representative from ACIS (Associação de Comercio e Indústria), Beira, April 2010. ACIS represents the interests of approximately 3 oo companies in the region. 
3. RENAMO - Resistência Nacional Moçambicana. The rebel movement was with the peace accord of 1992 transformed into a political party, opposing FRELIMO (Frente da Libertação de Moçambique), the party in power since Mozambican independence in 1975 .

4. <http://clubofmozambique.com/news/mozambique-is-suffering-a-military-expression-of-apolitical-problem/>, accessed 13.7 .2017 .

5. The IFIs (International Financial Institutions) were primarily the International Monetary Fund and the World Bank.

6. The company's aluminium production remained under the name Hydro, while the oil and gas division in 2007 merged with Statoil, the major company in the Norwegian oil industry.

7. Another concept used is 'agricultural supply chain' (OECD-FAO 2016).

8. Another option on Yara's agenda was the Southern Agricultural Growth Corridor (SAGCOT) in Tanzania.

9. Interview in Maputo, April 2010.

10. Interview in Beira, April 2010.

1 1. GAZEDA - Gabinete das Zonas Económicas de Desenvolivimento Acelerado.

12. CEPAGRI - Centro de Promocão da Agricultura - also represented the Mozambican government in the further planning of BAGC.

13. By 2011 , a new Strategic Plan for Agrarian Sector Development (PEDSA) was approved by the Mozambican Council of Ministers, referring to the Development Corridors as 'high-priority'.

14. Prorustica Ltd is an international development consultancy based in the UK. InfraCo is a project development and investment company, focusing on the development of infrastructure services. AgDevCo (Agricultural Development Company Ltd.) was established as a non-for-profit company in 2009 to operate in the agriculture sector in Africa, starting up in Mozambique. AgDevCo came to play a key role in the further development of BAGC.

15. Interview with Yara representative in Oslo, July 2010.

16. Interview with ACIS representative in Beira, April 2010.

17. Interviews with Yara staff, Oslo, June 2010 and May 2016.

18. <http://www.farmersweekly.co.za/archive/farmsecure-ties-up-yara-deal/>, accessed 10.7.2017.

19. News from the Norwegian Government, 22.2.201 1, translated from Norwegian.

20. UCAMA is the main organization of small farmers at the provincial level in Manica. It was formed in 1997 as an association within the national UNAC (União Nacional de Camponeses). Interviews were carried out at UCAMA's office in Chimoio, April 2010.

21. The ProSavana programme includes Tete in the Nacala Corridor.

22. Cf. Ellis \& Biggs (2001) and Vermeulen \& Cotula (2010) for critical reviews; while Collier \& Dercon (2014) argue for scale in facilitating commercialization. Smart \& Hanlon (2014) discuss questions of scale in Mozambican agricultural development.

23. Interviews with representatives of main donor agencies in Maputo, April 2010.

24. Interview with DfID staff, Maputo, April, 2010.

25. Interviews with the BAGC coordinator, in Maputo, and the BAGC advisor, in Chimoio, May 2011 .

26. Interviews with private-sector actors in Manica, May 201 1, and representatives of Banco Terra in Nampula and Maputo, May 2011.

27. Project Completion Review of 18.5.2017, <https://devtracker.dfid.gov.uk/projects/GB-1201862 /documents>, accessed 17.7.2017.

28. Interview with former Zimbabwean farmer in Manica, May 2011.

29. Project Completion Review of 18.5 .2017 , <https://devtracker.dfid.gov.uk/projects/GB-1201862 /documents>, accessed 17.7.2017.

30. Interview with Coordinator of the SDI Unit, Maputo, April 2010.

31. Project Completion Review of 18.5.2017, <https://devtracker.dfid.gov.uk/projects/GB-1201862 /documents>, accessed $17 \cdot 7.2017$.

\section{R E F E R E N C E S}

Abrahamsson, H. \& A. Nilsson. 1995. Mozambique: the troubled transition: from social construction to free market capitalism. London: Zed Books.

AgDevCo. 201 7. <http://www.agdevco.com/what-we-do/what-we-offer.html>, accessed 17.7.2017.

Åkesson, G., A. Calengo \& C. Tanner. 2008. 'Não é uma questão de fazer ou não fazer - é uma questão de como fazer'. Report, SLU, Sweden. <www.slu.se/Documents/externwebben/centrumbildningar-projekt/mkb>, accessed 10.7.2015. 
Alden Wily, L. 2012. 'Looking back to see forward: the legal niceties of land theft in land rushes', Journal of Peasant Studies 39, 3-4: $75^{1-75}$.

BAGC Report. 2010. 'Beira Agricultural Growth Corridor: Delivering the Potential', <http://www. agdevco.com/uploads/reports/BAGC_Investment_Blueprint_rpt19.pdf $>$, accessed 18.7.2017.

BAGC. 2012. <http://www.beiracorridor.com/?_target_=about-initiative $>$, accessed $14 \cdot 4 \cdot 2015$.

Beira Corridor. 2015. <http://www.beirainformation.com>, accessed 14.4.2015.

Borras, S.M. Jr. D. Fig and S. Monsalve Suárez. 2011. 'The politics of agrofuels and mega-land and water deals: insights for the ProCana case, Mozambique', Review of African Political Economy 38, 128 : $215^{-34}$.

Buur, L., C. Mondlane \& O. Baloi. 2011 . 'Strategic privatisation: rehabilitating the Mozambican sugar industry', Review of African Political Economy 38, 128 : $235^{-} 5^{6 .}$

Carnegie Consult. 2015. 'Financial Investment Advisory Technical Assistance: Final Report'. Maarssen, NL.

Chichava, S., J. Duran, L. Cabral, A. Shankland, L. Buckley, T. Lixia \& Z. Yue. 2013. 'Brazil and China in Mozambican agriculture: emerging insights from the field', IDS Bulletin 44, 4: 101-14.

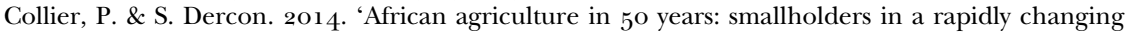
world', World Development 63: 92-101.

Cotula, L. 2012. 'The international political economy of the global land rush: a critical appraisal of trends, scale, geography and drivers', Journal of Peasant Studies 39, 3-4: 649-8o.

Cotula, L., S. Vermeulen, R. Leonard \& J. Keeley. 2009. 'Land Grab or Development Opportunity? Agricultural investment and international land deals in Africa'. London/Rome: IIED, FAO and IFAD. <www.fao.org/3/a-ak241e.pdf>, accessed 18.7.2017.

Edelman, M. 2013. 'Messy hectares: questions about the epistemology of land grabbing data', Journal of Peasant Studies 40, 3: 485-501.

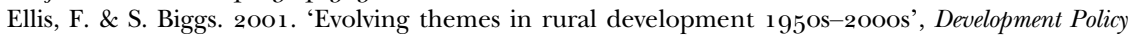
Review 19, 4: 437-48.

Eun, C.S. \& B.G. Resnick. 2007. International Financial Management. Fourth edition. Boston, MA: McGraw-Hill.

Fairbairn, M. 2013. 'Indirect dispossession: domestic power imbalances and foreign access to land in Mozambique', Development and Change 44, 2: $335^{-5} 5^{6}$.

Geertz, C. 1973. The Interpretation of Cultures. New York, NY: Basic Books.

Geffray, C. 1990. A Causa das Armas. Porto: Afrontamento.

Gengenbach, H. 1998. "I'll bury you in the border!': women's land struggles in post-war Facazisse (Magude District), Mozambique', Journal of Southern African Studies 24, 1: 7-36.

Hall, R. 2012. 'The next Great Trek? South African commercial farmers move north', Journal of Peasant Studies 39, 3-4: 823-43.

Hammar, A. 2013. 'Settling for less? Zimbabwean farmers and commercial farming in Mozambique', in W. Derman \& R. Kaarhus, eds. In the Shadow of a Conflict: crisis in Zimbabwe and its effects in Mozambique, South Africa and Zambia. Harare: Weaver Press, 92-1 20.

Hanlon, J. 1996. Peace without Profit: how the IMF blocks rebuilding in Mozambique. Oxford: James Currey.

Hanlon, J. 2011. 'Understanding Land Investment Deals in Africa: country report, Mozambique'. $<w w w . o a k l a n d i n s t i t u t e . o r g / . . . /$ files/OI_country_report_mozambique_o.pdf>, accessed 10.7.2015.

Hanlon, J. \& T. Smart. 2008. Do Bicycles Equal Development in Mozambique? Woodbridge: James Currey.

Kaarhus, R. \& S. Dondeyne. 2015. 'Formalising land rights based on customary tenure: community delimitation and women's access to land in central Mozambique', Journal of Modern African Studies 53, 2: $193^{-216 .}$

Kennedy, L. \& A. Sood. 2016. 'Greenfield Development as Tabula Rasa', Economic and Political Weekly LI, $17: 4^{1-9}$.

Kirshner, J. \& M. Power. 2015. 'Mining and extractive urbanism: postdevelopment in a Mozambican boomtown', Geoforum 61: 67-78.

Lagerkvist, J. 2014. 'As China returns: perceptions of land grabbing and spatial power relations in Mozambique', Journal of Asian and African Studies 49, 3: 251-66.

Lee, H.-H. \& J. Ries. 2016. 'Aid for trade and greenfield investment', World Development 84: 206-18.

Lubkemann, S. 2008. Culture in Chaos: an anthropology of the social condition in war. Chicago, IL: University of Chicago Press.

Massingue, N. 2015. 'Private investments trends in Mozambique: questions for reflection', in C.N. Castel-Branco, N. Massingue \& C. Muianga, eds. Questions on Productive Development in Mozambique. Maputo: IESE, 81-95. 
Meeuws, R. 2004. 'Trade and Transport Facilitation Audit', submitted to the World Bank. <http://site resources.worldbank.org/INTTLF/Resources/Mozambique_Final_Report.pdf $>$, accessed 18.7.2017.

Milgroom, J. 2015. 'Policy processes of a land grab: at the interface of politics 'in the air' and politics 'on the ground' in Massingir, Mozambique', Journal of Peasant Studies 42, 3-4: $585^{-606 .}$

Mitchell, J.C. 1984. 'Case studies', in R.F. Ellen, ed. Ethnographic Research. London: Academic Press, 237-41.

Myers, G.W. 1994. 'Competitive rights, competitive claims: land access in post-war Mozambique', Journal of Southern African Studies 20, 4: 603-32.

Negrão, J.G. 2003. 'Sistemas costumerios da terra', in B. Sousa Santos \& J.C. Trinidade, eds. Conflito $e$ Transformação Social: uma paisagem das justiças em Moçambique, Vol. 1. Porto: Afrontamento, 229-56.

Newitt, M. 1995. A History of Mozambique. London: Hurst \& Company.

Norwegian Government. 2011. <http://www.regjeringen.no/nb/dep/ud/aktuelt/nyheter>, accessed 22.2.2011.

Nuvunga, M. 2008. 'Region-building in central Mozambique: the case of the Zambezi Valley Spatial Development Initiative', in F. Söderbaum \& I. Taylor, eds. Afro-Regions: the dynamics of cross-border micro-regionalism in Africa. Uppsala: Nordiska Afrikainstitutet, 74-89.

OECD-FAO. 2016. OECD-FAO Guidance for Responsible Agricultural Supply Chains. <http://mneguide lines.oecd.org/OECD-FAO-Guidance.pdf $>$, accessed 24.9.2017.

Oliveira, G. de L.T. 2013. 'Land regularization in Brazil and the Global Land Grab', Development and Change 44, 2: 261-83.

Ouma, S., M. Boeckler \& P. Lindner. 2013. 'Extending the margins of marketization: frontier regions and the making of agro-export markets in northern Ghana', Geoforum 48: 225-35.

Palmer, K. 2010. 'Agricultural growth and poverty reduction in Africa: the case for patient capital'. <http://www.agdevco.com/images/stories/pdf/GENERAL_REPORTS/the_case_for_patient_ capital.pdf $>$, accessed 8.4.2010.

Pitcher, M.A. 2002. Transforming Mozambique: the politics of privatization, 1975-200o. Cambridge: Cambridge University Press.

Ribeiro, D. \& N. Matavel. 2009. 'Jatropha! A socio-economic pitfall for Mozambique'. Justiça Ambiental and União Nacional de Camponeses, Maputo. <www.viacampesina.net/downloads/ PDF/Report-Jatropha-JA-and-UNAC.pdf>, accessed 18.7.2017.

Schafer, J. \& R. Bell. 2002. 'The state and community-based natural resource management: the case of the Moribane forest reserve, Mozambique', Journal of Southern African Studies 28, 2: 401-20.

Schuetze, C. 2015. 'Narrative fortresses: crisis narratives and conflict in the conservation of Mount Gorongosa, Mozambique', Conservation and Society 13, 2: 141-53.

Scoones, I., R. Hall, S.M. Borras Jr., B. White \& W. Wolford. 2013. 'The politics of evidence: methodologies for understanding the global land rush', Journal of Peasant Studies 4o, 3: 469-83.

Shankland, A. \& E. Gonçalves. 2016. 'Imagining agricultural development in South-South Cooperation: the contestation and transformation of ProSAVANA', World Development 1 1: $35^{-4} 4^{6}$

Smart, R. \& J. Hanlon. 2014. Chickens and Beer: a recipe for agricultural growth in Mozambique. <http://bit. ly/chickens-beer>, accessed 1.6.2017.

Smith, J. 1988. The Beira Corridor Project. Geography 73, 3: 258-61.

Söderbaum, F. \& I. Taylor, eds. 2008a. Afro-Regions: the dynamics of cross-border micro-regionalism in Africa. Uppsala: Nordiska Afrikainstitutet.

Söderbaum, F. \& I. Taylor. 2008b. 'Competing region-building in the Maputo Development Corridor', in F. Söderbaum \& I. Taylor, eds. Afro-Regions: the dynamics of cross-border micro-regionalism in Africa. Uppsala: Nordiska Afrikainstitutet, $35^{-} 5^{2}$.

Tanner, C. 2011. 'Mozambique', in K. Kleinbooi \& R. De Satgé, eds. Decentralised Land Governance: case studies and local voices from Botswana, Madagascar and Mozambique. Cape Town: PLAAS, University of Western Cape. <http://www.plaas.org.za/plaas-publication/decentralised>, accessed 18.7 .2017 .

Taylor, I. 2003. 'Globalization and regionalization in Africa: reactions to attempts at neo-liberal regionalism', Review of International Political Economy 10, 2: 310-30.

U.S. Department of State. 2012. Investment Climate Statement-Mozambique. <http://www.state. gov/e/eb/rls/othr/ics/2012/191204.htm>, accessed 18.7.2017.

Vermeulen, S. \& L. Cotula. 2010. 'Making the most of agricultural investment: a survey of business models that provide opportunities for smallholders'. IIED/FAO/IFAD/SDC, London/Rome/ Bern. <www.ifad.org/pub/land/agri_investment.pdf>, accessed 18.7.2017.

Waterhouse, R. \& C. Vijfhuizen, eds. 2001. Strategic Women, Gainful Men: gender, land, and natural resources in different rural contexts in Mozambique. Maputo: Imprensa Universitária. 
West, H. \& G.W. Myers. 1996. 'A piece of land in a land of peace? State farm divestiture in Mozambique', Journal of Modern African Studies 34, 1: 27-51.

White, B., S.M. Borras Jr., R. Hall, I. Scoones \& W. Wolford. 201 2. 'The new enclosures: critical perspectives on corporate land deals', Journal of Peasant Studies 34, 3-4: 619-47.

Wolford, W. \& R. Nehring. 2015. 'Constructing parallels: Brazilian expertise and the commodification of land, labour and money in Mozambique', Canadian Journal of Development Studies 36, 2: 208-23.

Wolford, W., S.M. Borras Jr., R. Hall, I. Scoones \& B. White. 2013. 'Governing global land deals: the role of the state in the rush for land', Development and Change 44, 2: 189-210.

World Bank. 2010. 'Prospects for growth poles in Mozambique'. <http://siteresources.worldbank.org/ INTMOZAMBIQUE/Resources/FINALMozambiqueGrowthPolesAUG19.pdf>, accessed 18.7.2017.

Yara. 2011 . <http://www.yara.com/sustainability/africa_program/yara_and_africa/index.aspx $>$, accessed 25.2. 2011.

Yara. 2016. <http://www.yara.com/sustainability/how_we_engage/africa_engagement/index.aspx>, accessed $27 \cdot 5 \cdot 2016$. 